\title{
Pannexin Protein Expression in the Rat Middle Cerebral Artery
}

\author{
Alan R. Burns ${ }^{a, c}$ Sharon C. Phillips ${ }^{b}$ Elke M. Sokoya ${ }^{d}$ \\ ${ }^{\mathrm{a} C o l l e g e}$ of Optometry, University of Houston, and Departments of ${ }^{\mathrm{b}}$ Anesthesiology and ${ }^{\mathrm{c} P e d i a t r i c s,}$ \\ Baylor College of Medicine, Houston, Tex., USA; ${ }^{\mathrm{d}}$ Department of Human Physiology, Flinders University, \\ Adelaide, S.A., Australia
}

\section{Key Words}

Cell-to-cell communication - Cerebrovasculature $\cdot$

Hemichannels $\cdot$ Middle cerebral artery $\cdot$ Pannexins $\cdot$ Rat

\begin{abstract}
Background: Connexin proteins are well known to participate in cell-to-cell communication within the cerebral vasculature. Pannexins are a recently discovered family of proteins that could potentially be involved in cell-to-cell communication. Herein, we sought to determine whether pannexins are expressed in rat middle cerebral artery (MCA). Methods: A combination of RT-PCR, immunoblotting and immunohistochemistry techniques was used to characterize the expression pattern of pannexins in rat MCA. A fluorescent dye uptake approach in cultured smooth muscle cells was used to determine whether these cells have functional hemichannels. Results: We report for the first time that pannexins are expressed in the cerebral vasculature. We reveal that pannexin 1 is expressed in smooth muscle but not in endothelium and pannexin 2 is expressed in both endothelium and smooth muscle. Fluorescent dye entered cultured smooth muscle cells in the absence of extracellular calcium or when the cells were depolarized, which was prevented by the putative hemichannel blocker carbenoxolone. Conclusions: The identification of pannexins in rat MCA indicates that
\end{abstract}

pannexin expression is not restricted to neuronal cells. Dye uptake in cultured smooth muscle cells exhibited properties similar to those of connexin and pannexin hemichannels, which may represent another form of cell-to-cell communication within the vasculature. Copyright $\odot 2012$ S. Karger AG, Basel

\section{Introduction}

Within the cerebral vasculature, cell-to-cell communication is critical for modulating tone and thus blood flow. Large arteries in particular, such as the middle cerebral artery (MCA), play a major role in the regulation of cerebrovascular resistance [1]. Cells can communicate in two different ways, namely by gap junctional communication and paracrine signaling. In gap junctional communication, a direct exchange of signaling molecules via gap junctions (junctional channels) enables intercellular communication. Paracrine intercellular communication, on the other hand, does not involve direct intercellular signaling but rather the release of diffusible signaling molecules (such as calcium and ATP) that act on neighboring cells.

Historically, connexins were considered the exclusive structural protein of junctional and nonjunctional chan-

\section{KARGER \\ Fax +4161306 1234 \\ E-Mail karger@karger.ch}

www.karger.com
() 2012 S. Karger AG, Basel

1018-1172/12/0492-0101\$38.00/0

Accessible online at:

www.karger.com/jvr
Dr. Elke M. Sokoya

Department of Human Physiology, Flinders University

Room 6E136, Flinders Medical Centre

Flinders Drive, Bedford Park, SA 5042 (Australia)

Tel. +61 88204 5983, E-Mail elke.sokoya@ @ flinders.edu.au 
nels. However, 10 years ago, a new family of proteins called pannexins was identified [2]. Rather than forming gap junctions, pannexins appear to form hemichannels within the plasma membrane [3] and $\mathrm{Ca}^{2+}$-permeable channels in the endoplasmic reticulum [4]. To date, 3 pannexins have been described in the rodent and human genomes, namely pannexin 1 (Panx1), pannexin 2 (Panx2) and pannexin 3 (Panx3). Panx1 is ubiquitously expressed in many organs including the eye, thyroid, kidney, liver and central nervous system [5-7], while Panx2 appears to be more confined to the central nervous system $[8,9]$. Panx3 is localized to the skin, osteoblasts and chondrocytes [5]. Within the central nervous system, Panx1 has been reported in neurons and Purkinje cells [3] while Panx2 has been described in neurons [6, 8], and curiously its expression can be induced in astrocytes after ischemia/reperfusion injury [10].

Local changes in intracellular calcium can be propagated and regenerated along the vasculature, a phenomenon known as calcium wave propagation. Calcium waves have been recorded in both endothelial cells $[11,12]$ and smooth muscle cells $[13,14]$. The propagation of calcium waves involves both the release of ATP through hemichannels or 'nonjunctional channels' (paracrine signaling pathway) and the ensuing local activation of purinergic receptors by ATP to cause an increase in inositol triphosphate, which can then move directly through gap junctions to adjacent cells (direct gap junction pathway) [15]. While gap junctions comprising connexins have been implicated in calcium wave propagation within the vasculature [16], less is known regarding the composition of hemichannels. Pannexin hemichannels are prime candidates for the ATP release channel since, unlike connexin hemichannels, they can open at physiological calcium concentrations [17] and are highly permeable to ATP [18].

While connexins have been widely reported in cerebral arteries [19-21] and attributed to cerebral vascular function $[20,22,23]$, it is unknown whether their expression is shared with pannexins. In the present study, we sought to characterize the expression profile of Panx1 and Panx2 in the rat MCA. Our results indicate that Panx 1 is present in smooth muscle alone while Panx 2 is expressed in both endothelium and smooth muscle of rat MCA. Moreover, dye uptake studies in cell culture suggest that smooth muscle cells may have functional hemichannels that are comprised of connexins and possibly pannexins. The presence of pannexins within the cerebrovasculature suggests that they may contribute to the regulation of vascular tone in the brain.

\section{Materials and Methods}

Experiments were carried out in accordance with the National Institutes of Health guidelines for the care and use of laboratory animals and were approved by the Animal Protocol Review Committee at Baylor College of Medicine. Male Long-Evans rats (275-325 g) were housed under a 12-hour light/12-hour dark cycle with unrestricted access to food and water.

\section{Cell Digestion Protocol}

MCAs were removed from the rat brain, cleaned of connective tissue and placed in a digestion buffer containing (in $\mathrm{mmol} / \mathrm{l}$ ) $\mathrm{NaCl}$ (135), $\mathrm{KCl}$ (5), $\mathrm{MgCl}_{2}$ (1.5), $\mathrm{Na}_{2} \mathrm{HPO}_{4}$ (0.42), $\mathrm{NaH}_{2} \mathrm{PO}_{4}$ (0.44), $\mathrm{NaHCO}_{3}$ (4.2), HEPES (10) and $1 \mathrm{mg} / \mathrm{ml} \mathrm{BSA} \mathrm{(pH} \mathrm{7.25).}$ MCAs were cut into pieces and enzymatically dissociated with 18 $\mathrm{U} / \mathrm{ml}$ papain and $1 \mathrm{mg} / \mathrm{ml}$ dithioerythritol $\left(35 \mathrm{~min}\right.$ at $\left.37^{\circ} \mathrm{C}\right), 1.2$ $\mathrm{mg} / \mathrm{ml}$ collagenase II, $0.8 \mathrm{mg} / \mathrm{ml}$ soybean trypsin inhibitor and 60 $\mathrm{U} / \mathrm{ml}$ elastase $\left(10 \mathrm{~min}\right.$ at $\left.37^{\circ} \mathrm{C}\right)$. The tissue was washed several times with digestion buffer between enzymatic incubations. Single smooth muscle cells or small endothelial cell clusters were visually identified with a microscope and isolated by micropipette.

Pannexin Message Expression Using RT-PCR

Extraction of Total RNA and cDNA Synthesis from MCAs

Two MCAs were harvested from the brain of a male rat under sterile conditions and snap-frozen in liquid nitrogen. Frozen vessels were pulverized with a pestle, and total RNA was extracted using the RNeasy ${ }^{\circledR}$ Micro Kit (Qiagen) according to the manufacturer's instructions. mRNA was reverse transcribed to generate first-strand cDNA using random hexamers. Synthesis of cDNA was performed with SuperScript II (Invitrogen) with the following incubation times: $5 \mathrm{~min}$ at $65^{\circ} \mathrm{C}, 12 \mathrm{~min}$ at $25^{\circ} \mathrm{C}, 50 \mathrm{~min}$ at $42^{\circ} \mathrm{C}$ and $15 \mathrm{~min}$ at $70^{\circ} \mathrm{C}$. RNase $\mathrm{H}$ was added and incubated for $20 \mathrm{~min}$ at $37^{\circ} \mathrm{C}$ to degrade any remaining RNA.

Extraction of RNA and cDNA Synthesis from Single Cells

MCAs were enzymatically digested (see Cell Digestion Protocol above), and the cells were viewed on the stage of an inverted microscope. With the aid of suction, a micropipette [prefilled with RNAlater (Qiagen)] was used to specifically draw either 50100 endothelial cells or smooth muscle cells into the tip. The cells were then expelled into a PCR tube and snap-frozen in liquid $\mathrm{N}_{2}$. cDNA was synthesized with a one-step method. The following reagents were added directly to the tube containing $2 \mu \mathrm{l}$ of cells: $2 \mu \mathrm{l}$ of $5 \times 1$ st strand buffer, $0.5 \mu \mathrm{l}$ of $10 \mathrm{mmol} / \mathrm{l}$ deoxynucleotide triphosphate, $1 \mu \mathrm{l}$ of $50 \mu \mathrm{mol} / \mathrm{l}$ random hexamer, $1 \mu \mathrm{l}$ of 0.1 $\mathrm{mmol} / \mathrm{l} \mathrm{DTT}, 1 \mu \mathrm{l}$ of $10 \mathrm{U} / \mu \mathrm{l}$ RNase Inhibitor and $1.5 \mu \mathrm{l}$ of diethylpyrocarbonate-treated water. The cells were lysed by exposing them to 2 freeze-thaw cycles, and then $1 \mu$ l of 50 U/ $\mu$ l Super Script II Reverse Transcriptase (Invitrogen) was added. cDNA was synthesized during a 1 -hour incubation at $42^{\circ} \mathrm{C}$.

Polymerase Chain Reaction

PCR amplification was performed with $0.2 \mu$ of Platinum Taq DNA polymerase, $1 \times$ PCR Buffer, $1.5 \mathrm{mmol} / 1 \mathrm{MgCl}_{2}, 0.2 \mathrm{mmol} / 1$ deoxynucleotide triphosphate mixture and $1 \mu \mathrm{mol} / \mathrm{l}$ of each primer for 40 cycles. Primer pairs were as follows: 5'-TAAACCCCA-GCTATGGAGCCA-3' (forward) and 5'-GGCGTCAGTAAAATCCCGTTC-3' (reverse) for Panx1; 5'-GGCCCCGTAAGAAAATGAAGT-3' (forward) and 5'-TGTATCCGTGGCT- 
GT-CTTCCT-3' (reverse) for Panx2; 5'-AGCTGTCACATCACCCCACT-GT-3' (forward) and 5'-TGTGCGAGTGACATGATGCTG-3' (reverse) for Panx3, and 5'-GGCTGCCTTCTCTTGTGACAA-3' (forward) and 5'-CGCTC-CTGGAAGATGGTGAT-3' (reverse) for GAPDH. All primer pairs were designed using Primer Express (Applied Biosystems, Calif., USA), with the exception of GAPDH [24]. The annealing temperature was $55^{\circ} \mathrm{C}$ for Panx $1,60^{\circ} \mathrm{C}$ for $\operatorname{Panx} 2$ and $56^{\circ} \mathrm{C}$ for Panx3. For the negative control, reverse transcriptase was omitted. The RT-PCR products were analyzed by electrophoresis on a $1.8 \%$ agarose gel containing ethidium bromide, in parallel with a 50-base pair DNA ladder (Invitrogen). The DNA fragments were visualized and photographed using a UV light table/camera documentation system. The predicted sizes of the PCR amplification products specific to Panx1, Panx2, Panx3 and GAPDH are 125, 140, 101 and 180 base pairs, respectively. Sequencing was performed at the Child Health Research Center Core Laboratory (Baylor College of Medicine).

\section{Pannexin Protein Expression Using Immunoblotting}

Protein Isolation

The MCAs were harvested from the brain, cleaned of connective tissue and snap-frozen in liquid nitrogen. Pooled frozen MCAs were pulverized with a pestle, homogenized in a modified RIPA buffer and centrifuged ( $8 \mathrm{~min}$ at $14,000 \mathrm{rpm})$. A portion of the supernatant was used for total protein analysis (modified Lowry assay) and a portion was loaded onto the gel.

\section{Western Gel and Transfer}

MCA homogenate was combined with Laemmli buffer and boiled for $5 \mathrm{~min}$. Then, 2.5-20 $\mu \mathrm{g}$ of protein was loaded onto each lane of the gel (7.5\% SDS-PAGE gel). The MCA homogenate was run in parallel with a standard (Precision Plus Protein Dual Color Standard, Invitrogen). The gel was run at room temperature at $90 \mathrm{~V}$ for $1.5 \mathrm{~h}$ and then transferred onto an Immobilon-P membrane (Millipore) at $4^{\circ} \mathrm{C}(1.5 \mathrm{~h}$ at $250 \mathrm{~mA}$ with stirring). The membrane was blocked in 5\% Bio-Rad Blotting Grade Blocker containing $0.1 \%$ Tween-20 in $1 \times$ PBS (BB) for $1 \mathrm{~h}$. This was followed by incubation overnight at $4{ }^{\circ} \mathrm{C}$ in primary antibody diluted in $50 \%$ BB (1:20,000 Panx1 dilution or 1:50,000 Panx2 dilution) against each pannexin protein. The membrane was washed in PBS and incubated in secondary antibody (antirabbit IgG, 1:10,000 dilution with $50 \% \mathrm{BB}$ ) conjugated to horseradish peroxidase. The membrane was then placed in Pierce SuperSignal ${ }^{\circledR}$ West Femto Maximum Sensitivity Substrate followed by exposure to film. To confirm that each lane contained equivalent amounts of protein, the membrane was stripped with Restore ${ }^{\mathrm{TM}}$ Western Blot Stripping Buffer (Pierce) and then probed for anti-GAPDH (Calbiochem; 1:100,000 dilution). Rat brain was used as a positive control $[5,6]$. For negative controls, we (1) omitted the primary antibody, (2) incubated the homogenate with nonimmune rabbit IgG and (3) incubated the homogenate with the appropriate immunogenic peptide.

Generation of Pannexin Antibodies

For the generation of a rat Panx1 (rPanx1) and a rat Panx2 (rPanx2) antibody, two amino acid peptide sequences, CMSLQTKGEDQGSQR (corresponding to amino acids 383-396) and CSAEPPVVKRPRKKM (corresponding to amino acids 408 421), respectively, were selected for their immunogenicity using PCGENE. BLAST database searches indicated that these sequenc- es were unique to their respective protein. Each peptide was synthesized and conjugated via a cysteine residue added at the $\mathrm{N}$ terminus during synthesis. Two rabbits were immunized to each peptide, and the sera were affinity purified. Affinity purification yielded final antibody concentrations of $0.5 \mathrm{mg} / \mathrm{ml}(\mathrm{rPanx} 1)$ and $1.5 \mathrm{mg} / \mathrm{ml}$ (rPanx2). Synthesis of peptides, rabbit immunization and affinity purification of the antibodies were performed by Sigma-Genosys (The Woodlands, Tex., USA).

Pannexin Protein Localization Using Immunohistochemistry Preparation of MCA Cross-Sections

Rats were anesthetized with pentobarbital (50 mg/kg, i.p.). The vascular system was perfused by a transcardial approach with heparinized saline solution $(20 \mathrm{units} / \mathrm{ml})$ at a pressure of 80 $\mathrm{mm} \mathrm{Hg}$. The brain was removed and a wedge containing the MCA was harvested and snap-frozen in dry ice-chilled 2-methylbutane. Cryosections $\left(10 \mu \mathrm{m}\right.$ thick, $\left.-20^{\circ} \mathrm{C}\right)$ were mounted onto Superfrost Plus slides (Fisher Scientific), air dried and stored at $-80^{\circ} \mathrm{C}$.

Immunofluorescence Light Microscopy

MCA cross-sections were washed in PBS and then fixed with $4 \%$ paraformaldehyde in PBS for $30 \mathrm{~min}$ at $4^{\circ} \mathrm{C}$. Following a wash step in PBS, sections were permeabilized $(0.1 \%$ Tween-20) and blocked (10\% goat serum, $0.5 \%$ BSA). Sections were incubated with either Panx1 primary antibody (1:35 dilution), Panx2 primary antibody (1:300 dilution) or rabbit IgG (Jackson ImmunoResearch Labs) overnight at $4^{\circ} \mathrm{C}$. Immunohistochemical labeling was demonstrated by incubation with Alexa Fluor 594-conjugated goat antirabbit IgG (1:500 dilution) for $30 \mathrm{~min}$ at room temperature. Specimens were incubated (10 min at room temperature) in $1 \mu \mathrm{mol} / \mathrm{l}$ DAPI (Molecular Probes) for nuclei detection, rinsed in PBS, mounted using Airvol and allowed to dry in air overnight. Pannexin immunolabeling was captured with an epifluorescence microscope (Nikon TE2000U) and deconvolved using AutoDeblur software (Media Cybernetics Inc).

Primary Culture of Rat Aorta Smooth Muscle Cells

Smooth muscle cells were cultured from the rat thoracic aorta and used after the first passage. The rat aorta was dissected and transferred to a sterile dish containing cold DMEM and antibiotics (100 U/ml penicillin, $100 \mathrm{mg} / \mathrm{ml}$ streptomycin). The connective tissue was removed and the aorta pinned onto a silicone-covered preparation dish. The vessel was cut open longitudinally and the endothelium was gently removed with curved forceps. The medial layer was then stripped off in small pieces and deposited in a T25 culture flask which was set upright in a tissue incubator. After $24-48 \mathrm{~h}$, the flask was placed horizontally, and culture medium (DMEM/F12 containing 10\% FBS, $100 \mathrm{U} / \mathrm{ml}$ penicillin and $100 \mathrm{mg} / \mathrm{ml}$ streptomycin) was changed every $48 \mathrm{~h}$. The media explants were removed between days 7 and 10 before the cells were passaged and plated onto $35-\mathrm{mm}$ petri dishes at low densities so that single cells predominated.

\section{Dye Uptake Experiments}

Cultured rat aorta smooth muscle cells were used at passage 1. Cells were exposed to either HEPES buffer with $1 \mathrm{mmol} / \mathrm{C} \mathrm{CaCl}_{2}$ (normal calcium), HEPES buffer with no $\mathrm{CaCl}_{2}$ and $2 \mathrm{mmol} / \mathrm{l}$ EGTA (zero calcium) or high-potassium buffer. For the high-potassium experiments, the culture medium was replaced with either HEPES buffer (normal $\mathrm{K}^{+}$) containing (in $\mathrm{mmol} / \mathrm{l}$ ) $\mathrm{NaCl}$ 
Fig. 1. RT-PCR products for Panx1 (125 bp), Panx2 (140 bp) and Panx3 (101 bp) were found in rat brain and rat MCA. GAPDH (180 bp) was used as an internal control. Lane 1: 50-bp ladder (size marker). No product was detected if reverse transcriptase was omitted (data not shown). Data are representative of 3 separate preparations.

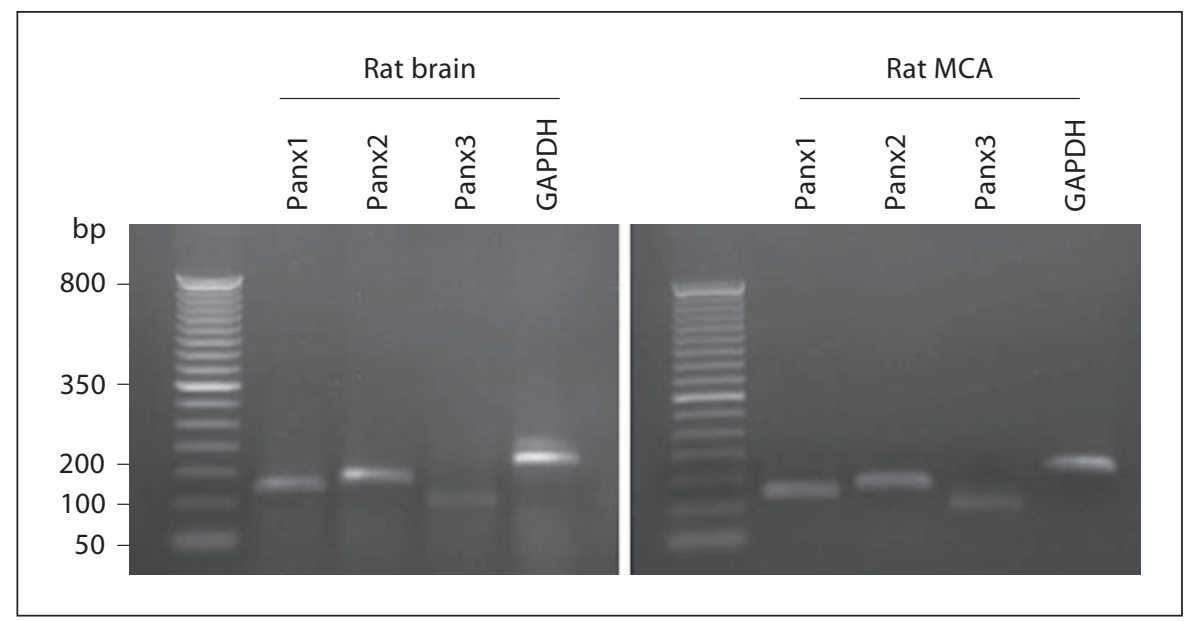

(120), potassium gluconate (4.2), $\mathrm{Na}_{2} \mathrm{HPO}_{4}(0.9)$, sodium pyruvate (1.2), glucose (10), HEPES (20) and $\mathrm{CaCl}_{2}$ (1) or isotonic high- $\mathrm{K}^{+}$ buffer containing (in $\mathrm{mmol} / \mathrm{l}) \mathrm{NaCl}(4.2)$, potassium gluconate (120), $\mathrm{Na}_{2} \mathrm{HPO}_{4}(0.9)$, sodium pyruvate (1.2), glucose (10) and HEPES (20). Lucifer Yellow was added to the bath at a concentration of $0.5 \%$ for $5 \mathrm{~min}$. After a brief wash, Lucifer Yellow was imaged with an epifluorescence microscope. In some experiments, hemichannels were blocked by adding $100 \mu \mathrm{mol} / \mathrm{l}$ carbenoxolone. The integrity of cell membranes was confirmed by adding Lucifer Yellow in conjunction with $0.4 \%$ rhodamine B isothiocyanatedextran.

\section{Results}

\section{Expression of Pannexin Message in Rat MCA}

Transcripts for Panx1 and Panx2 were detected in both rat brain and rat MCA (fig. 1). While Panx3 was also detected, this was only marginal. PCR products were not detected when template cDNA was omitted from the PCR or when reverse transcription reactions were performed in the absence of reverse transcriptase (data not shown). Sequencing of the pannexin products indicated that the bands corresponded to Panx1 (NM_199397), Panx2 (NM_199409) and Panx3 (NM_199398). In freshly dissociated endothelial cells, message encoding Panx2 but not Panx1 was detected (fig. 2a). RT-PCR products indicating the presence of endothelial nitric oxide synthase and absence of SM22 $\alpha$ confirmed the purity of the endothelial cell sample. Freshly dissociated smooth muscle cells demonstrated PCR product for both Panxl and Panx2 message (fig. 2b). The purity of the smooth muscle cell preparation was confirmed by the presence of PCR amplicons for SM22 $\alpha$ but not for endothelial nitric oxide synthase.

\section{Expression of Pannexin Protein in Rat MCA}

To determine whether pannexin protein was expressed in rat MCA, we used immunoblotting and generated our own rabbit polyclonal anti-Panx1 and anti-Panx2 antibodies. Since our RT-PCR data showed very weak message for Panx3, we decided to focus on the expression profile of Panx1 and Panx2.

To investigate Panx1 protein expression in the rat MCA, protein extracts were assayed for Panx1 expression by Western blot. Panxl was weakly expressed in rat MCA, although GAPDH protein expression was confirmed in our sample (fig. 3a). No band was detected in either rat brain or rat MCA when the primary antibody was incubated with the control peptide (fig. 3a), when the primary antibody was replaced with nonimmune rabbit IgG or when the primary antibody was omitted (data not shown). By contrast, affinity-purified rPanxl antisera recognized a single band at $58 \mathrm{kDa}$ in rat brain, tissue known to express high levels of Panx1 [5, 6] (fig. 3a), but not in lung (online suppl. fig. S1; for all online suppl. material, see www.karger.com/doi/10.1159/000332329), tissue known to lack Panx1 [5]. These results are consistent with previous studies in rat brain showing a $58-\mathrm{kDa}$ isoform that is associated with the plasma membrane $[9,25]$. The $58-\mathrm{kDa}$ band is $11 \mathrm{kDa}$ larger than the predicted size but has been shown to represent the glycosylated protein expressed on the cell surface [26].

To investigate Panx2 protein expression in the rat MCA, protein extracts were assayed for Panx2 expression by Western blot. Panx 2 was shown to be highly expressed in rat MCA (fig. 3b). Each band was absent when the primary antibody was incubated with the control peptide (fig. 3b), when the primary antibody was replaced with 


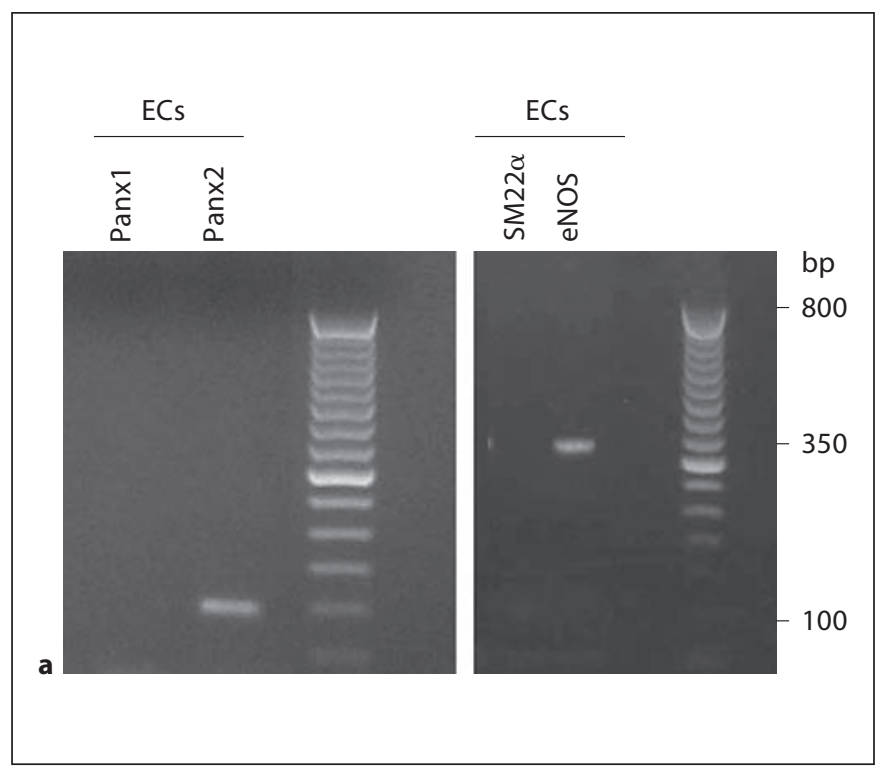

Fig. 2. RT-PCR product for Panx $2(140 \mathrm{bp})$ was found in freshly dissociated endothelial cells (ECs; a, left panel) and RT-PCR products for Panx1 (125 bp) and Panx2 (140 bp) were found in freshly dissociated smooth muscle cells (SMCs; $\mathbf{b}$, left panel) from rat MCA. The right panels show RT-PCR products indicating the absence of

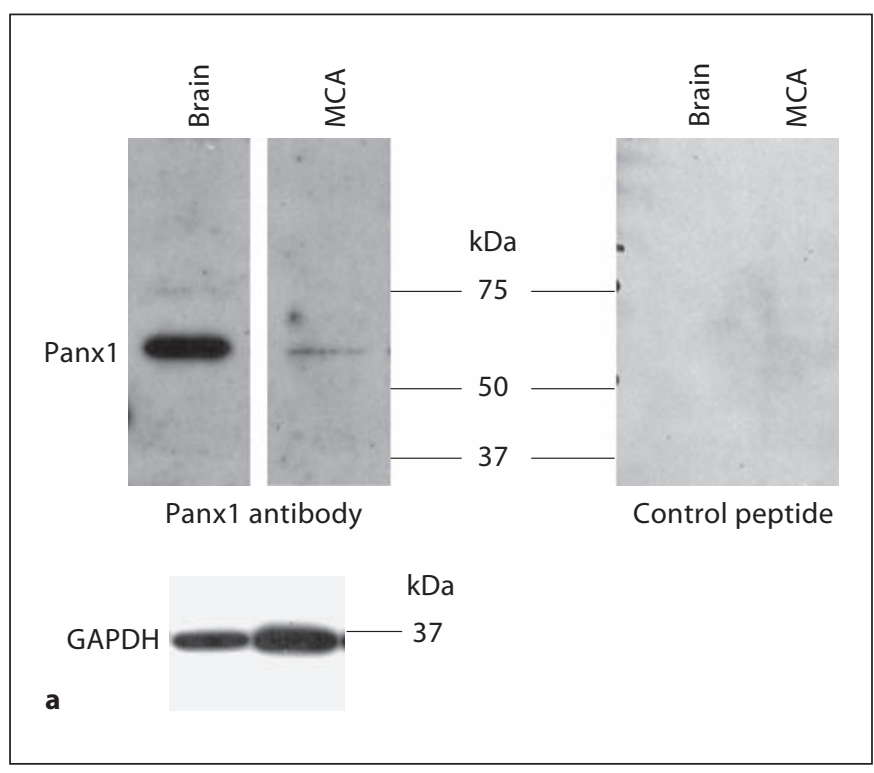

Fig. 3. a Tissue extracts from rat brain $(10 \mu \mathrm{g})$ and MCA $(20 \mu \mathrm{g})$ were run on $10 \%$ SDS-PAGE gels and probed with Panx 1 antibody in the absence and presence of the control peptide. $\mathbf{b}$ Tissue extracts from rat brain $(10 \mu \mathrm{g})$ and MCA $(2.5 \mu \mathrm{g})$ were run on $10 \%$ SDS-PAGE gels and probed with Panx 2 antibody in the absence

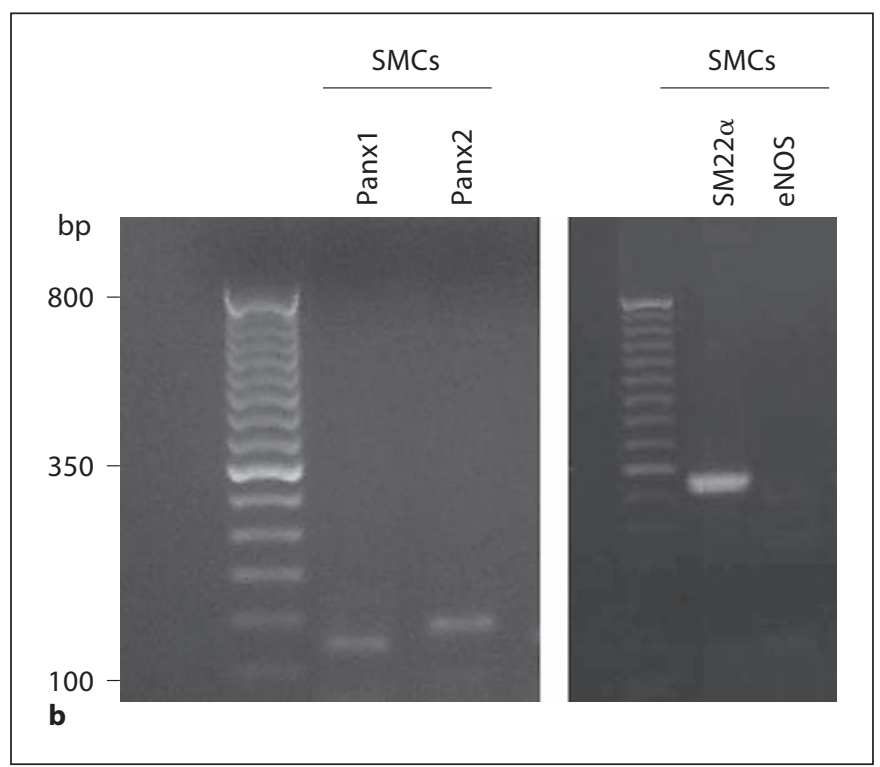

SM $22 \alpha$ ( 325 bp) and the presence of endothelial nitric oxide synthase (eNOS; 356 bp) in dissociated endothelial cells (a, right panel) and vice versa in dissociated smooth muscle cells (b, right panel). No product was detected if reverse transcriptase was omitted (data not shown). Data are representative of 3 separate preparations.

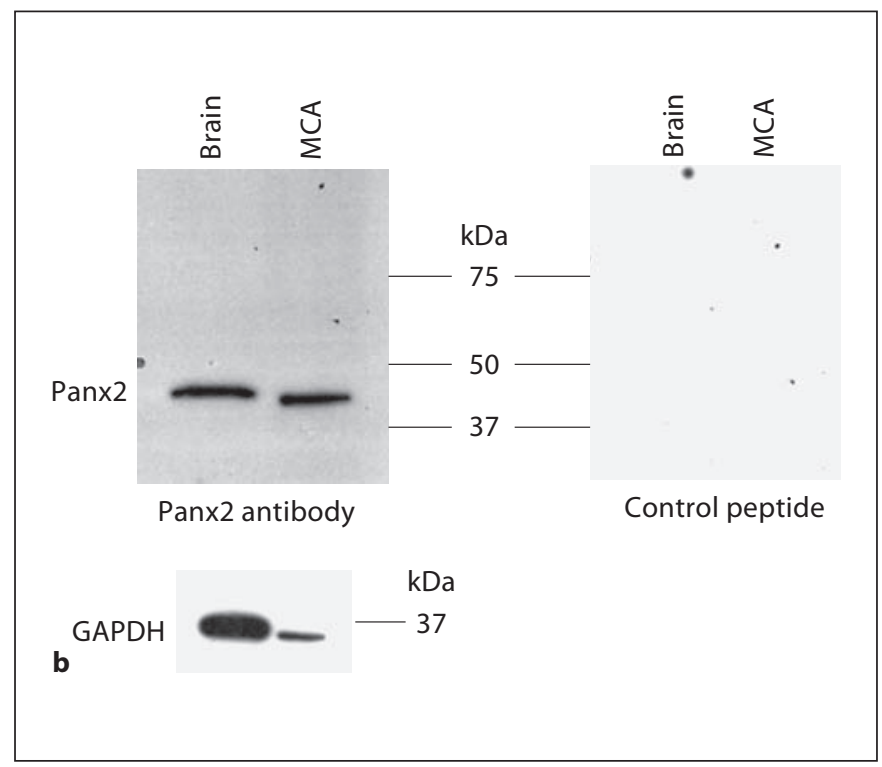

and presence of the control peptide. Each band disappeared when the primary antibody was incubated with the control peptide. Each membrane was stripped and reprobed for GAPDH. The molecular mass is indicated. Data are representative of 4 separate preparations. 


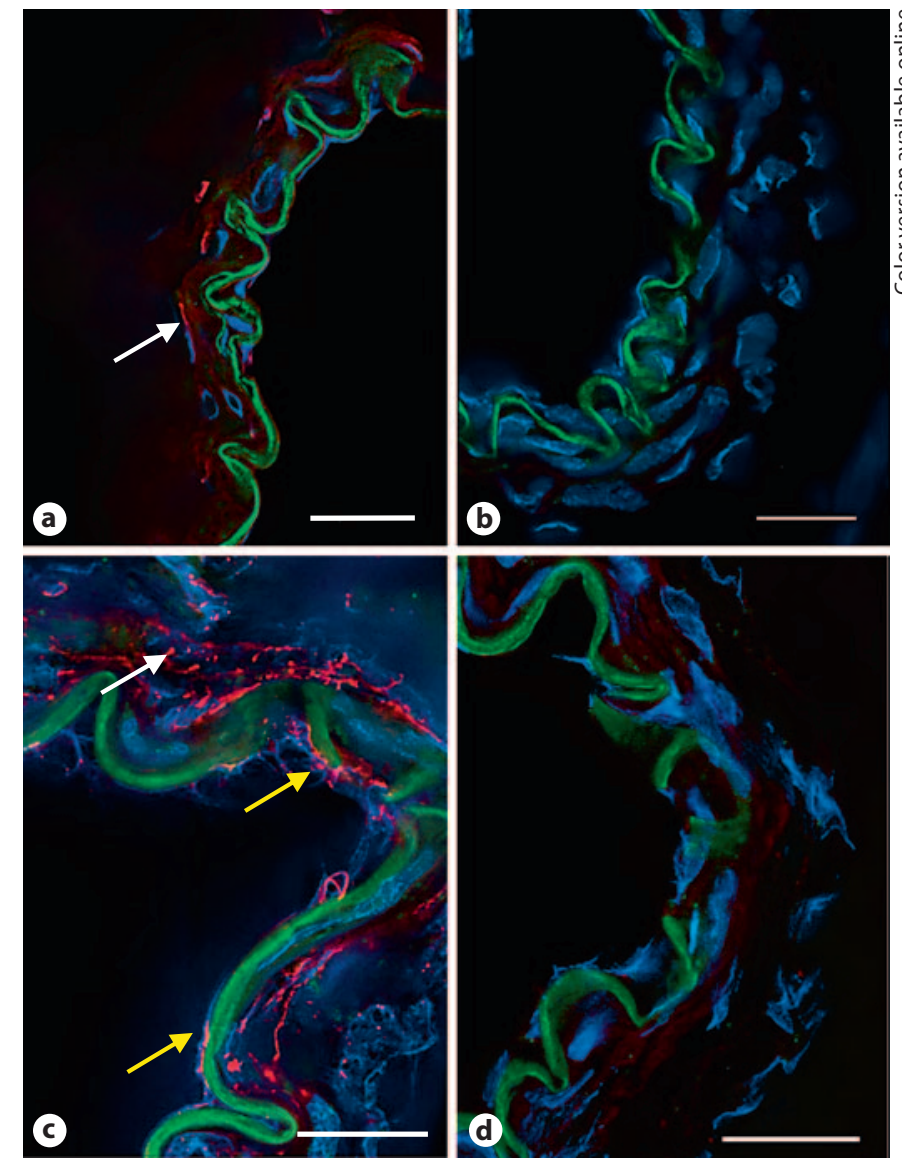

Fig. 4. Pannexin immunofluorescence in frozen cross-sections of rat MCA. a Panxl fluorescence (red) showed weak staining in smooth muscle (arrow) and was undetected in endothelial cells. b Red fluorescence was absent in sections in which the control rabbit IgG was substituted for the primary antibody. c Panx2 fluorescence (red) was detected in both endothelial cells (bottom two arrows) and smooth muscle cells (top arrow). d Red fluorescence was absent in sections incubated with a control rabbit IgG. Green fluorescence is the autofluorescence of the internal elastic lamina that separates the endothelium from smooth muscle. Blue fluorescence identifies nuclei labeled with DAPI. Data are representative of 3 separate preparations. Scale bar $=20 \mu \mathrm{m}$. (Color only in online version).

nonimmune rabbit IgG or when the primary antibody was omitted (data not shown). Affinity-purified rPanx2 antisera recognized a single band at $47 \mathrm{kDa}$ in rat brain, tissue known to express Panx 2 at high levels $[5,6]$, but not in lung (online suppl. fig. S1), tissue known to lack Panx2 [5].

\section{Localization of Pannexin Immunofluorescence}

To characterize the localization of Panx1 within the cells of the vascular wall, immunohistochemical staining was performed on frozen MCA cross-sections. Panx 1 immunofluorescence showed a weak signal in the smooth muscle of MCA cross-sections and no signal in the endothelium (fig. 4a). These findings are consistent with the RT-PCR data in freshly dissociated vascular cells (fig. 2).

In frozen cross-sections, Panx 2 fluorescence was detected in both endothelial cells and smooth muscle cells of rat MCA (fig. 4c). Again this is consistent with the detection of Panx2 message in endothelial and smooth muscle cell populations (fig. 2).

\section{Assessment of Hemichannel Function by Dye Uptake}

Primary cultured rat smooth muscle cells were confirmed as smooth muscle cells based on positive staining for both smooth muscle cell $\alpha$-actin (online suppl. fig. S2) and myosin heavy chain and absence of staining for von Willebrand factor (data not shown). Note that fibroblasts are positive for smooth muscle cell $\alpha$-actin but negative for myosin heavy chain. These data underscore the high purity of smooth muscle cells in our preparation. These cells also showed positive staining for connexin (Cx) 43 (online suppl. fig. S2), and Western blot analysis confirmed that they expressed Panx2 (online suppl. fig. S3).

The functional state of hemichannels in cultured smooth muscle cells was assessed by the cellular uptake of Lucifer Yellow from the extracellular media. When cells were exposed to zero extracellular calcium solution, they showed a significant increase in Lucifer Yellow fluorescence which was prevented in the presence of the hemichannel blocker carbenoxolone (fig. 5a). Similar findings were also seen in response to depolarization with high potassium (fig. 5b). Lucifer Yellow fluorescence was absent when dextran-rhodamine was added to the bath, indicating that cell injury does not account for the dye uptake since dextran-rhodamine $(3,000 \mathrm{Da})$ is too large to move through hemichannels.

\section{Discussion}

Within the cerebral vasculature, cell-to-cell communication is critical for modulating tone and thus blood flow. There is abundant literature implicating a role for connexin gap junctions in promoting endothelial calcium changes in response to smooth muscle-dependent agonists [27], conducted vasomotor responses [22, 28], myogenic responses [23, 29], cerebral vasomotion [20] and endothelium-dependent dilations [21,30]. However, it is currently not known whether pannexin hemichannels are present within the cerebral vasculature. 
Fig. 5. Evidence of functional hemichannels in rat aorta smooth muscle cells. a In the normal calcium-containing medium, no significant Lucifer Yellow uptake was observed $(n=10)$. However, in the medium containing zero calcium, hemichannelmediated dye uptake was observed that was blocked in the presence of $100 \mu \mathrm{mol} / \mathrm{l}$ carbenoxolone (CBX; $\mathrm{n}=8)$. $\mathbf{b}$ In normal extracellular potassium, no significant Lucifer Yellow uptake was observed $(n=7)$. However, when cells were depolarized with high potassium, hemichannel-mediated dye uptake was observed that was blocked in the presence of $100 \mu \mathrm{mol} / \mathrm{l} \mathrm{car}$ benoxolone $(\mathrm{n}=8)$. Scale bar $=100 \mu \mathrm{m}$.
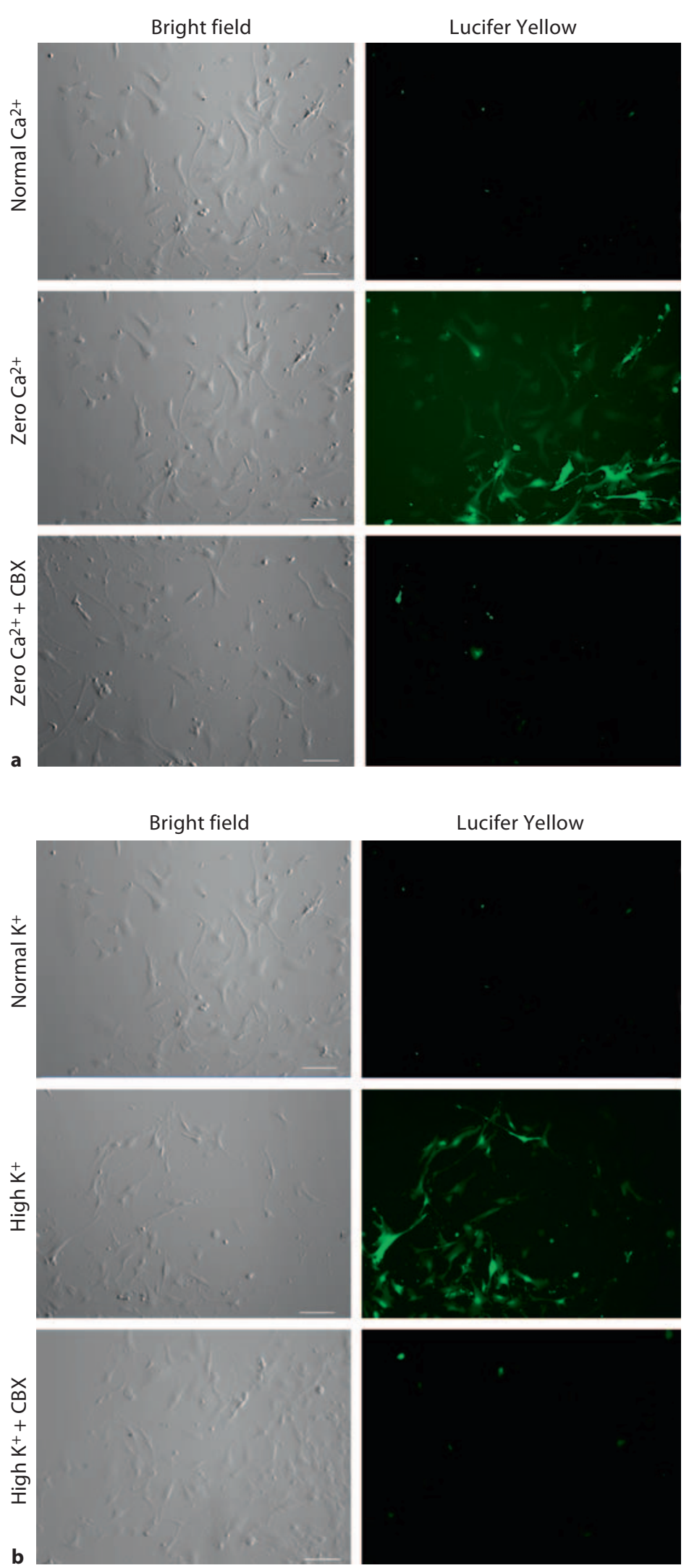
The present study provides an initial characterization of pannexin expression in the rat MCA. We provide the following new data: (1) Panx1 protein is weakly expressed in smooth muscle but not in endothelium; (2) Panx2 protein is expressed in both endothelium and smooth muscle, and (3) cultured smooth muscle cells exhibit functional properties similar to those of connexin and pannexin hemichannels.

To our knowledge, this is the first report of pannexin expression within the vasculature of the brain. As this paper was being reviewed, a report was published demonstrating that Panx1, but not Panx2, is expressed in thoracodorsal resistance arteries [31]. Interestingly, evidence was also presented suggesting an association between Panxl and the $\alpha_{1}$-adrenergic receptor where Panxl opens to release purines to enhance phenylephrine-induced vasoconstriction.

Previous studies from our laboratory have shown that the endothelium of rat MCA expresses Cx40 and Cx43 while the smooth muscle expresses Cx37 and Cx40 [21]. Other cell types have also been found to coexpress connexins and pannexins. For example, cortical astrocytes express both Cx43 [32] and Panx1 [33]. However, erythrocytes express Panx1 but not connexins [34]. Connexin expression is known to be dependent upon the vascular bed and even species studied. Therefore, it will be interesting to see whether this also holds true for pannexin expression.

It is currently difficult to unequivocally demonstrate the presence of functional hemichannels. Unfortunately, there are no pharmacological agents that can discriminate between connexins and pannexins, and even the more specific mimetic peptides have been shown to be promiscuous [35]. Carbenoxolone is a derivative of glycyrrhetinic acid that blocks both connexin and pannexin hemichannels [36]. It has been shown to block dye uptake and ATP release in pannexin-expressing cells [34]. Carbenoxolone has also been shown to block volume-regulated anion channels [37] and $\mathrm{P}_{2} \mathrm{X}_{7}$ receptors [38]; however, Pelegrin and Surprenant [39] showed that the latter was due to the functional coupling between Panxl and $\mathrm{P}_{2} \mathrm{X}_{7}$ receptors and that carbenoxolone had no effect in single astrocytes transfected with $\mathrm{P}_{2} \mathrm{X}_{7}$.

Our fluorescent dye uptake results in cultured smooth muscle cells are consistent with the presence of functional hemichannels. Note that these cells were plated at low densities, thereby ruling out a potential gap junction-mediated transfer of dye between cells. Connexin, but not pannexin, hemichannels are sensitive to changes in extracellular calcium $[17,39]$. Therefore, the increase in Lu- cifer Yellow fluorescence seen in smooth muscle cells after depletion of extracellular calcium suggests connexin hemichannel opening (fig. 5a). This is most likely mediated by $\mathrm{Cx} 43$ since (1) this is the predominant connexin protein expressed in rat aorta smooth muscle [40] (online suppl. fig. S2) and (2) Lucifer Yellow dye uptake was blocked in the presence of carbenoxolone.

Under normal extracellular calcium conditions, depolarization of cultured smooth muscle cells with high potassium caused an increase in cellular Lucifer Yellow fluorescence which was blocked by carbenoxolone (fig. 5b). Since Cx43-expressing cells have failed to show hemichannel currents in response to depolarizing voltages [41, 42], our data are consistent with the activation of pannexin hemichannels.

During pathological insults such as ischemia, vascular connexin hemichannels could be activated during episodes of significantly reduced extracellular calcium. On the other hand, pannexin hemichannels could be activated during conditions of cellular depolarization such as traumatic brain injury [43], stroke [44] and subarachnoid hemorrhage [45]. Under normal conditions, Panx1 could contribute to the propagation of calcium waves within the vasculature by mediating the release of ATP [18] and as such play an important role in mediating vascular tone. In addition to forming hemichannels on the plasma membrane, recent findings have also indicated that pannexins form calcium-permeable channels within the endoplasmic reticulum $[4,46]$. Given the fundamental role of calcium homeostasis in controlling vascular tone and cerebral blood flow $[47,48]$, pannexins may play a vital role in the regulation of vasodilatation.

The identification of pannexins in the rat MCA indicates that pannexin expression is not limited to neuronal/ astrocytic cell populations within the central nervous system. Further studies are required to understand the role of pannexin hemichannels within the vasculature and their functional differences compared to connexin hemichannels. The possibility that pannexins may be an important therapeutic target during pathologies such as stroke and traumatic brain injury warrants further investigation.

\section{Acknowledgments}

The authors acknowledge the technical assistance of Dr. Jie Chen. This work was supported by the National Institutes of Health Grants HL72954 (E.M.S.), and AI46773, HL42550 and HL070537 (A.R.B.). 


\section{References}

$\checkmark 1$ Faraci FM, Heistad DD: Regulation of large cerebral arteries and cerebral microvascular pressure. Circ Res 1990;66:8-17.

-2 Panchin Y, Kelmanson I, Matz M, Lukyanov K, Usman N, Lukyanov S: A ubiquitous family of putative gap junction molecules. Curr Biol 2000;10:R473-R474.

- 3 MacVicar BA, Thompson RJ: Non-junction functions of pannexin-1 channels. Trends Neurosci 2010;33:93-102.

-4 Vanden Abeele F, Bidaux G, Gordienko D, Beck B, Panchin YV, Baranova AV, Ivanov DV, Skryma R, Prevarskaya N: Functional implications of calcium permeability of the channel formed by pannexin 1. J Cell Biol 2006;174:535-546.

5 Bruzzone R, Hormuzdi SG, Barbe MT, Herb A, Monyer H: Pannexins, a family of gap junction proteins expressed in brain. Proc Natl Acad Sci USA 2003;100:13644-13649.

6 Vogt A, Hormuzdi SG, Monyer H: Pannexin1 and Pannexin2 expression in the developing and mature rat brain. Brain Res Mol Brain Res 2005;141:113-120.

7 Weickert S, Ray A, Zoidl G, Dermietzel R: Expression of neural connexins and pannexin1 in the hippocampus and inferior olive: a quantitative approach. Brain Res Mol Brain Res 2005;133:102-109.

-8 Ray A, Zoidl G, Weickert S, Wahle P, Dermietzel R: Site-specific and developmental expression of pannexin 1 in the mouse nervous system. Eur J Neurosci 2005;21:3277-3290.

-9 Dvoriantchikova G, Ivanov D, Panchin Y, Shestopalov VI: Expression of pannexin family of proteins in the retina. FEBS Lett 2006;580:2178-2182.

-10 Zappala A, Li Volti G, Serapide MF, Pellitteri R, Falchi M, La Delia F, Cicirata V, Cicirata F: Expression of pannexin2 protein in healthy and ischemized brain of adult rats. Neuroscience 2007;148:653-667.

11 Moerenhout M, Himpens B, Vereecke J: Intercellular communication upon mechanical stimulation of CPAE- endothelial cells is mediated by nucleotides. Cell Calcium 2001; 29:125-136

-12 Uhrenholt TR, Domeier TL, Segal SS: Propagation of calcium waves along endothelium of hamster feed arteries. Am J Physiol Heart Circ Physiol 2007;292:H1634-H1640.

- 13 Missiaen L, Oike M, Bootman MD, De Smedt H, Parys JB, Casteels R: Vasopressin responses in electrically coupled A7r5 cells. Pflugers Arch 1994;428:283-287.

- 14 Zang WJ, Balke CW, Wier WG: Graded alpha1-adrenoceptor activation of arteries involves recruitment of smooth muscle cells to produce 'all or none' $\mathrm{Ca}(2+)$ signals. Cell Calcium 2001;29:327-334.

15 Locovei S, Wang J, Dahl G: Activation of pannexin 1 channels by ATP through P2Y receptors and by cytoplasmic calcium. FEBS Lett 2006;580:239-244.
6 de Wit C, Wolfle SE, Hopfl B: Connexin-dependent communication within the vascular wall: contribution to the control of arteriolar diameter. Adv Cardiol 2006;42:268-283.

17 Bruzzone R, Barbe MT, Jakob NJ, Monyer H: Pharmacological properties of homomeric and heteromeric pannexin hemichannels expressed in Xenopus oocytes. J Neurochem 2005;92:1033-1043.

18 Bao L, Locovei S, Dahl G: Pannexin membrane channels are mechanosensitive conduits for ATP. FEBS Lett 2004;572:65-68.

19 Little TL, Beyer EC, Duling BR: Connexin 43 and connexin 40 gap junctional proteins are present in arteriolar smooth muscle and endothelium in vivo. Am J Physiol 1995; 268:H729-H739.

20 Haddock RE, Grayson TH, Brackenbury TD, Meaney KR, Neylon CB, Sandow SL, Hill CE: Endothelial coordination of cerebral vasomotion via myoendothelial gap junctions containing connexins 37 and 40. Am J Physiol Heart Circ Physiol 2006;291:H2047 H2056.

21 Sokoya EM, Burns AR, Setiawan CT, Coleman HA, Parkington HC, Tare M: Evidence for the involvement of myoendothelial gap junctions in EDHF-mediated relaxation in the rat middle cerebral artery. Am J Physio Heart Circ Physiol 2006;291:H385-H393.

22 Segal SS, Duling BR: Flow control among microvessels coordinated by intercellular conduction. Science 1986;234:868-870.

23 Earley S, Resta TC, Walker BR: Disruption of smooth muscle gap junctions attenuates myogenic vasoconstriction of mesenteric resistance arteries. Am J Physiol Heart Circ Physiol 2004;287:H2677-H2686.

24 Fujita A, Takeuchi T, Saitoh N, Hanai J, Hata F: Expression of $\mathrm{Ca}(2+)$-activated $\mathrm{K}(+)$ channels, SK3, in the interstitial cells of Cajal in the gastrointestinal tract. Am J Physiol Cell Physiol 2001;281:C1727-C1733.

25 Dvoriantchikova G, Ivanov D, Pestova A, Shestopalov V: Molecular characterization of pannexins in the lens. Mol Vis 2006;12: 1417-1426.

26 Boassa D, Ambrosi C, Qiu F, Dahl G, Gaietta G, Sosinsky G: Pannexin1 channels contain a glycosylation site that targets the hexamer to the plasma membrane. J Biol Chem 2007; 282:31733-31743.

27 Dora KA, Doyle MP, Duling BR: Elevation of intracellular calcium in smooth muscle causes endothelial cell generation of $\mathrm{NO}$ in arterioles. Proc Natl Acad Sci USA 1997;94: 6529-6534.

28 Segal SS, Duling BR: Conduction of vasomotor responses in arterioles: a role for cell-tocell coupling? Am J Physiol 1989;256:H838H845.

29 Rivers RJ: Remote effects of pressure changes in arterioles. Am J Physiol 1995;268:H1379_ H1382.
30 Sandow SL, Tare M, Coleman HA, Hill CE, Parkington HC: Involvement of myoendothelial gap junctions in the actions of endothelium-derived hyperpolarizing factor. Circ Res 2002;90:1108-1113.

- 31 Billaud M, Lohman AW, Straub AC, LooftWilson R, Johnstone SR, Araj CA, Best AK, Chekeni F, Ravichandran K, Penuela S, Laird DW, Isakson BE: Pannexin1 regulates $\alpha 1$ adrenergic receptor-mediated vasoconstriction. Circ Res 2011;109:80-85.

32 Yamamoto T, Ochalski A, Hertzberg EL, Nagy JI: LM and EM immunolocalization of the gap junctional protein connexin 43 in rat brain. Brain Res 1990;508:313-319.

33 Barbe MT, Monyer H, Bruzzone R: Cell-cell communication beyond connexins: the pannexin channels. Physiology (Bethesda) 2006; 21:103-114

34 Locovei S, Bao L, Dahl G: Pannexin 1 in erythrocytes: function without a gap. Proc Natl Acad Sci USA 2006;103:7655-7659.

- 35 Mather S, Dora KA, Sandow SL, Winter P, Garland CJ: Rapid endothelial cell-selective loading of connexin 40 antibody blocks endothelium-derived hyperpolarizing factor dilation in rat small mesenteric arteries. Circ Res 2005;97:399-407.

36 Spray DC, Ye ZC, Ransom BR: Functional connexin 'hemichannels': a critical appraisal. Glia 2006;54:758-773.

-37 Benfenati V, Caprini M, Nicchia GP, Rossi A, Dovizio M, Cervetto C, Nobile M, Ferroni S: Carbenoxolone inhibits volume-regulated anion conductance in cultured rat cortical astroglia. Channels (Austin) 2009;3:323336.

-38 Suadicani SO, Brosnan CF, Scemes E: P2X7 receptors mediate ATP release and amplification of astrocytic intercellular Ca2+ signaling. J Neurosci 2006;26:1378-1385.

-39 Pelegrin P, Surprenant A: Pannexin-1 mediates large pore formation and interleukin1beta release by the ATP-gated P2X7 receptor. EMBO J 2006;25:5071-5082.

40 van Kempen MJ, Jongsma HJ: Distribution of connexin37, connexin 40 and connexin 43 in the aorta and coronary artery of several mammals. Histochem Cell Biol 1999;112: 479-486.

-41 White TW, Deans MR, O’Brien J, Al-Ubaidi MR, Goodenough DA, Ripps H, Bruzzone R: Functional characteristics of skate connexin 35 , a member of the gamma subfamily of connexins expressed in the vertebrate retina. Eur J Neurosci 1999;11:1883-1890.

42 Hoang QV, Qian H, Ripps H: Functional analysis of hemichannels and gap-junctional channels formed by connexins 43 and 46 . Mol Vis 2010;16:1343-1352. 
43 Hartings JA, Strong AJ, Fabricius M, Manning A, Bhatia R, Dreier JP, Mazzeo AT, Tortella FC, Bullock MR; Co-Operative Study of Brain Injury Depolarizations: Spreading depolarizations and late secondary insults after traumatic brain injury. J Neurotrauma 2009; 26:1857-1866.

-44 Dohmen C, Sakowitz OW, Fabricius M, Bosche B, Reithmeier T, Ernestus RI, Brinker G, Dreier JP, Woitzik J, Strong AJ, Graf R; Co-Operative Study of Brain Injury Depo- larizations (COSBID): Spreading depolarizations occur in human ischemic stroke with high incidence. Ann Neurol 2008;63: 720-728.

45 Iadecola C: Bleeding in the brain: killer waves of depolarization in subarachnoid bleed. Nat Med 2009;15:1131-1132.

46 Penuela S, Bhalla R, Gong XQ, Cowan KN, Celetti SJ, Cowan BJ, Bai D, Shao Q, Laird DW: Pannexin 1 and pannexin 3 are glycoproteins that exhibit many distinct charac- teristics from the connexin family of gap junction proteins. J Cell Sci 2007;120:37723783.

47 Nelson MT, Patlak JB, Worley JF, Standen NB: Calcium channels, potassium channels, and voltage dependence of arterial smooth muscle tone. Am J Physiol 1990;259:C3C18.

48 Graier WF, Sturek M, Kukovetz WR: Ca2+ regulation and endothelial vascular function. Endothelium 1994;1:223-236. 